\title{
Synthesis and biological evaluation of mannose-6-phosphate-coated multivalent dendritic cluster glycosides
}

\author{
Oruganti Srinivas, ${ }^{a}$ S. Radhika, ${ }^{a}$ Narasimha Murthy Bandaru, ${ }^{a}$ Siva Kumar Nadimpalli ${ }^{* b}$ and \\ Narayanaswamy Jayaraman*a \\ a Department of Organic Chemistry, Indian Institute of Science, Bangalore 560 012, India \\ ${ }^{b}$ Protein Biochemistry and Molecular Biology Laboratory, Department of Biochemistry, \\ University of Hyderabad, Hyderabad 500 046.E-mail: jayaraman@orgchem.iisc.ernet.in; \\ Fax: 91-80-2360-0529
}

Received 6th May 2005, Accepted 23rd September 2005

First published as an Advance Article on the web 31st October 2005

\begin{abstract}
The synthesis of multivalent dendritic cluster glycosides of mannopyranosyl-6-phosphate is presented. Poly(amido amine)-based dendrimers of 0.5-3.5 generations, containing carboxylic acid peripheral functionalities, were utilized so as to install 4, 8, 16 and 32 mannopyranosyl-6-phosphate residues at the peripheries of the dendrimers. Amide bond formation between an amine-tethered mannopyranosyl-6-phosphate monomer unit and carboxylic acid-functionalized dendrimers was conducted to synthesize the dendritic cluster glycosides. The constitutions of the Man-6-P-containing dendrimers were assessed by ${ }^{1} \mathrm{H},{ }^{13} \mathrm{C}$ and ${ }^{31} \mathrm{P}$ NMR spectroscopies and the sugar content analysis by a resorcinol assay. Preliminary biological studies with few newly synthesized Man-6-P-containing dendrimers showed that these compounds could bind the purified goat liver mannose 6-phopshate receptor (MPR 300) protein.
\end{abstract}

\section{Introduction}

Phosphorylated and phosphosugar structures form major components of natural glycosylated biomacromolecules, such as proteophosphoglycans and lipophosphoglycan, present abundantly in pathogenic parasites and poly(glycosyl phosphates). ${ }^{1}$ In some of these phosphoglycans, the phosphoryl components are composed of repeating units of Man-1-P and Gal- $\beta-(1-4)-$ Man- $\alpha-1-P$ residues, as in the case of Leishmania genus. ${ }^{2}$ These phosphorylated glycosides act as biological signals. Mannose-6phosphate (Man-6-P), in particular, is known to be involved in the selective targeting of newly synthesized enzymes to lysosomes. ${ }^{3}$ It is known that the presence of multiple Man-6$\mathrm{P}$ residues on $N$-linked oligosaccharides lead to binding affinity enhancements to the cation-independent Man-6-P receptors in macrophages and such enhanced binding affinities have been attributed to the so-called 'glycoside cluster effect' ${ }^{4}$ In the light of the importance of the glycoside cluster effect in carbohydrateprotein interactions, a large number of synthetic cluster glycosides have been synthesized and their lectin recognition properties resulting from clustering the sugar ligands studied. ${ }^{5}$ Cluster glycosides built up on dendritic scaffolds have occupied considerable interest in recent years. ${ }^{6}$ The hyperbranched and unimolcular nature of dendrimers add as yet another newer scaffold for the presentation of clustered sugar ligands, and on the basis of dendritic design principles, several dendritic cluster glycosides have been synthesized and their properties studied. ${ }^{7}$ Dendrimers constructed with phosphorylated building blocks might be considered as highly branched analogs of naturally-occurring phosphorylated glycosides and thus have a potential to incorporate them in studies directed towards understanding the functions of phosphorylated glycoconjugates. We report herein the synthesis of phosphorylated sugarcontaining dendrimers, in which the phosphorylated sugar units are presented at the peripheries of the dendrimers. In the synthesis of phosphorylated sugar-coated dendrimers, Man-6$\mathrm{P}$ sugar units were attached at the peripheries of a series of poly(amido amine) (PAMAM) dendrimers.

\section{Results and discussion}

The covalent modification of the peripheries of dendrimers was performed by forming amide bonds between amine-tethered sugar units and carboxylic acid-functionalized PAMAM dendrimers. Pre-formed PAMAM dendrimers ${ }^{8}$ of $0.5,1.5,2.5$ and 3.5 generations, possessing 4, 8, 16 and 32 carboxylic acid groups, respectively, were utilized to obtain the Man-6-Pcontaining dendrimers. Synthesis of amine-tethered Man-6-P derivative 5 was initiated from $N$-(benzyloxycarbonylamino)ethyl-2,3,4,6-tetra- $O$-benzoyl- $\alpha$-D-mannopyranoside (1). Derivative 1 was modified sequentially as: (i) deprotection of the $O$-benzoyl protecting groups; (ii) $O$-tritylation of the primary hydroxy group; and (iii) $O$-benzoylation of the remaining hydroxy groups to afford 2 (Scheme 1). De- $O$-tritylation of 2 and phosphorylation of $\mathbf{3}$, with chlorodimethyl phosphate in pyridine, provided the Man-6-P derivative 4. Hydrogenolysis of the benzyloxycarbonyl protecting group in $\mathbf{4}$ led to the isolation of the free amine-tethered Man-6-P derivative 5. Alternatively, $O$-benzoyl group deprotection of 4 led to the isolation of the free hydroxy group-containing Man-6-P derivative 6.

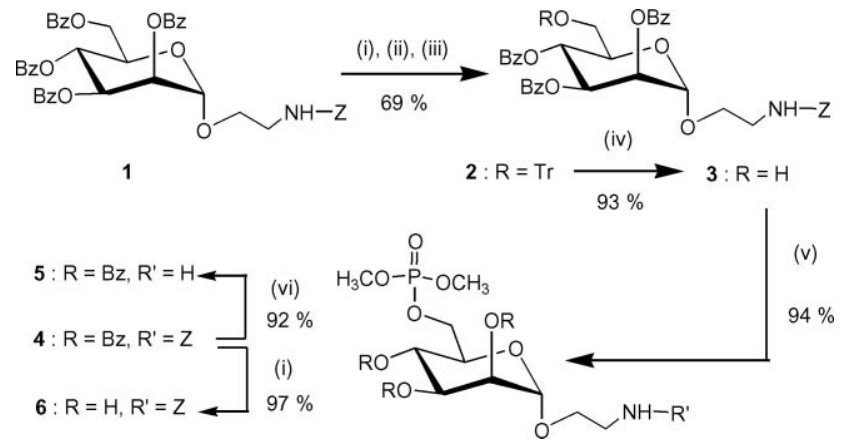

Scheme 1 Reagents and conditions: (i) $0.5 \mathrm{M} \mathrm{NaOMe} / \mathrm{MeOH}$; (ii) $\mathrm{TrCl}$, $\mathrm{Py}, 70^{\circ} \mathrm{C}, 3 \mathrm{~h}$; (iii) $\mathrm{BzCl}, \mathrm{Py}, 12 \mathrm{~h}$; (iv) $\mathrm{HCOOH}-\mathrm{THF}-\mathrm{H}_{2} \mathrm{O}(1: 1: 0.1)$, $50{ }^{\circ} \mathrm{C}, 2 \mathrm{~h}$; (v) (O)P(OMe) ${ }_{2} \mathrm{Cl}, \mathrm{Py},-40{ }^{\circ} \mathrm{C} \rightarrow \mathrm{rt}, 24 \mathrm{~h}$; (vi) $\mathrm{H}_{2}, 10 \% \mathrm{Pd}-\mathrm{C}$, MeOH-EtOAc $(1: 1), 12 \mathrm{~h}, \mathrm{rt}$.

Amine $\mathbf{5}$ was subjected to amide bond formation with pre-formed PAMAM dendrimers. Thus, the reaction of 5 with PAMAM dendrimers (0.5 generation), having four carboxylic acid groups, in the presence of di-isopropylcarbodiimide (DIC)/1-hydroxybenzotriazole (HOBt), followed by deprotection of the $O$-benzoyl groups with $\mathrm{NaOMe} / \mathrm{MeOH}$ afforded the tetravalent Man-6-P-functionalized first generation dendrimer 7 


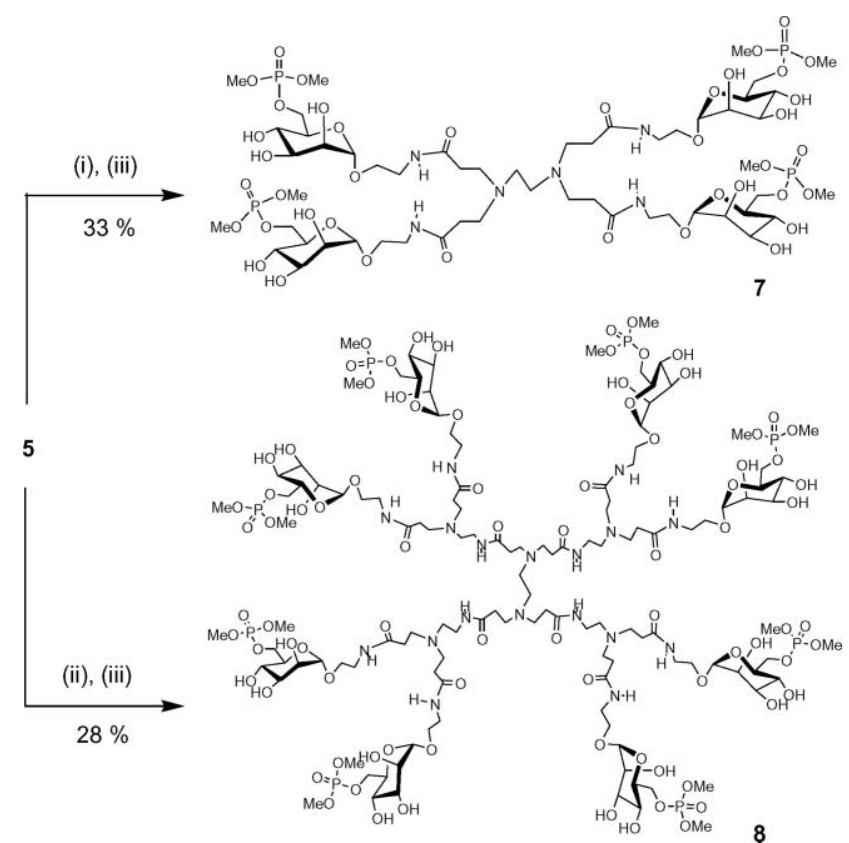

Scheme 2 Reagents and conditions: (i) PAMAM $\mathrm{G}_{0.5}-(\mathrm{COOH})_{4}, \mathrm{DIC}$, HOBt, DMF, rt, 24 h; (ii) PAMAM G ${ }_{1.5}-(\mathrm{COOH})_{8}$, EDC/NHS, DMF, rt, 24 h; (iii) $\mathrm{NaOMe} / \mathrm{MeOH}, \mathrm{rt}, 3 \mathrm{~h}$.

(Scheme 2). To functionalize the higher generation dendrimers, activation of the carboxylic acid groups was performed using 1-ethyl-3-(3-dimethylaminopropyl)carbodiimide (EDC) and $N$-hydroxysuccinimide (NHS) in DMF. Thus, EDC/NHSmediated activation of the higher generation carboxylic acidfunctionalized dendrimers $(1.5,2.5$ and 3.5 generations, having 8,16 and 32 carboxylic acid functionalities, respectively), followed by amidation with amine $5 \mathrm{in}$ DMF led to the formation of multivalent $O$-benzoyl group-protected Man-6-P-containing PAMAM dendrimers. These protected sugar-containing dendrimers were purified before deprotection by gel permeation chromatography (GPC), with THF as the eluent. Fractions eluting with early retention times were collected and the solvents removed. The GPC chromatograms of the protected compounds showed retention times centered at: $O$-benzoyl-protected 8 (7.45 min); $O$-benzoyl-protected 9 (7.15 min); $O$-benzoylprotected $10(6.98 \mathrm{~min})$. The resulting product was subjected to $O$-benzoyl group deprotection $(\mathrm{NaOMe} / \mathrm{MeOH})$ and the free Man-6-P-functionalized dendrimers 8-10 were thus obtained (Schemes 2, 3 and 4, respectively). The structural nature of the dendrimers was assessed by ${ }^{1} \mathrm{H},{ }^{13} \mathrm{C}$ and ${ }^{31} \mathrm{P}$ NMR spectroscopies and the sugar content analysis by a resorcinol assay. The protected Man-6-P derivative 4 had shown the presence of two OMe groups of the phosphate moiety as a double doublet, centered at $3.69 \mathrm{ppm}$ in the ${ }^{1} \mathrm{H}$ NMR spectrum. In the ${ }^{13} \mathrm{C}$ NMR spectrum of 4, a resonance corresponding to the OMe groups was observed at $54.5 \mathrm{ppm}\left(J_{\mathrm{P}, \mathrm{C}}=6.5 \mathrm{~Hz}\right)$. Similarly, the phosphorus nucleus was observed at $1.10 \mathrm{ppm}$ in the ${ }^{31} \mathrm{P}$ NMR spectrum of 4 . The presence of the dimethylphosphate moiety in $\mathbf{6}$, obtained after treatment of 4 with $\mathrm{NaOMe} / \mathrm{MeOH}$, was confirmed by the above NMR spectroscopies. Mass spectral analysis of $\mathbf{6}$ provided the molecular ion peak as the corresponding $\mathrm{K}$ adduct.

The presence of two methoxy groups of the phosphate moiety and also the phosphorus nucleus in $\mathbf{7 - 1 0}$ were confirmed by ${ }^{1} \mathrm{H}$, ${ }^{13} \mathrm{C}$ and ${ }^{31} \mathrm{P}$ NMR spectroscopies. The extent of functionalization was inferred from the ${ }^{1} \mathrm{H}$ NMR integration of the anomeric proton of the sugar units and one of the methylene protons of the dendritic core. Specifically, a comparison of the integrations of the resonances corresponding to the anomeric $\mathrm{H}-1$ proton (ca. $5.0 \mathrm{ppm}$ ) of the sugar unit and the resonance corresponding to the methylene protons $(2.69-2.87 \mathrm{ppm})$, adjacent to the carbonyl group functionalities, were indicative of the extent

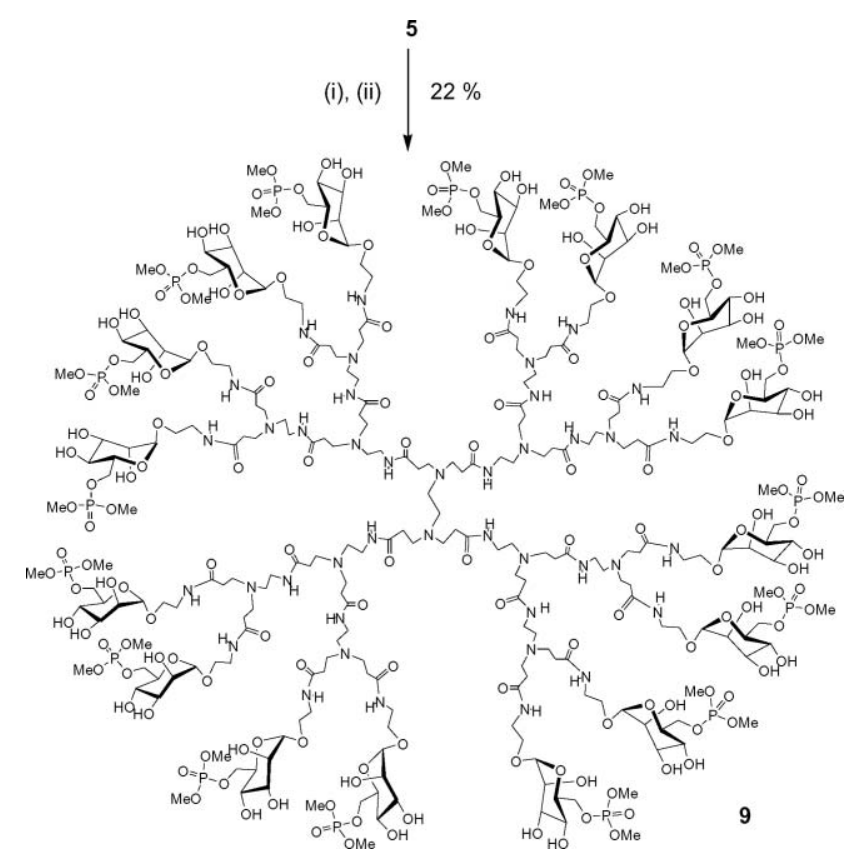

Scheme 3 Reagents and conditions: (i) PAMAM $\mathrm{G}_{2.5}-(\mathrm{COOH})_{16}$, EDC/NHS, DMF, rt, 24 h; (ii) $0.5 \mathrm{M} \mathrm{NaOMe/MeOH,} \mathrm{rt,} 12$ h.

of functionalization. This comparison indicated that while 7 , 8 and 9 were fully functionalized with Man-6-P units, about 30 Man-6-P units were present in the case of 10. The anomeric carbon resonance in the ${ }^{13} \mathrm{C}$ NMR spectra appeared at $c a$. $99.5 \mathrm{ppm}$ and ${ }^{31} \mathrm{P}$ NMR spectra showed the phosphate moiety at $c a$. $1.0-2.0 \mathrm{ppm}$. Mass spectral and elemental composition analysis of 7-10 were attempted. Mass spectral analysis by FABMS, MALDI-TOF-MS and ESI-MS ionization modes were not successful to secure the molecular ion peak. On the other hand, the hygroscopic nature of the compounds led to inability to obtain reliable elemental composition values from the elemental analysis.

The extent of mannose-6- $O$-phosphate substitution on the PAMAM dendrimers was confirmed by colorimetric determination using resorcinol-sulfuric acid assay. ${ }^{9}$ This microtiter plate assay method is used widely for the estimation of the percentage of sugar substitution in neoglycoproteins, glycolipids and macromolecules such as glycopolymers. ${ }^{10}$

The percentage of sugar moieties in the final free sugarcontaining dendrimers $\mathbf{7 - 1 0}$ was determined in comparison to $\alpha$-D-mannose, which was utilized as the standard. The results of this assay are presented in Table 1. From this analysis, the number of mannose-6- $O$-phosphate residues present in derivatives 7 and 8 was found to be 4 and 8 , respectively, confirming the complete substitution of Man-6-P at the peripheries of first and second generation PAMAM dendrimers. In the case of derivatives 9 and 10, the percentage sugar content related to the presence of only 15-16 and 28-29 Man-6-P residues, respectively. These results correlate with the number of Man-6-P moieties, as determined by ${ }^{1} \mathrm{H}$ NMR spectral analysis.

In order to analyze if the synthetic compounds made in this study can bind a receptor protein, preliminary biological studies were carried out. For this purpose, the putative goat liver MPR 300 protein (cation-independent receptor) was chosen. ${ }^{11}$ In a protocol, the monomeric (6), tetrameric (7) and octameric (8) compounds were immobilized to Seralose gels, denoted as Seralose-M, Seralose-T and Seralose-O gels, respectively. The purified goat MPR 300 protein was separately incubated with these gels and processed as described in the Experimental section. SDS-PAGE analysis of the eluted samples revealed that the receptor, bound on these gels, could be eluted with $7.5 \mathrm{mM}$ mannose 6-phosphate. Under the same conditions, the phosphomannan-Sepharose gel that was used to purify the 
Table 1 Analysis of the number of sugar residues by resorcinol-sulfuric acid method ${ }^{a}$

\begin{tabular}{lllc}
\hline & Calculated sugar content $^{b}(\%)$ & Observed sugar content $^{c, d}(\%)$ & Number of mannose residues $^{(0)}$ \\
\hline $\mathbf{7}$ & 44.4 & 44.8 & 4 \\
$\mathbf{8}$ & 40.0 & 40.1 & 8 \\
$\mathbf{9}$ & 37.5 & 36.3 & $15-16$ \\
$\mathbf{1 0}$ & 36.6 & 32.6 & $28-29$
\end{tabular}

${ }^{a}$ Aliquots of glycodendrimer solutions in water were in the concentration range $1.2-0.2 \mathrm{mg} \mathrm{mL}^{-1} .{ }^{b}$ The calculated percentage weight of mannose present in glycodendrimers based on complete substitution. ${ }^{c}$ All the samples were assayed in triplicate. ${ }^{d}$ Error: $\pm 0.3-0.5 \%$.

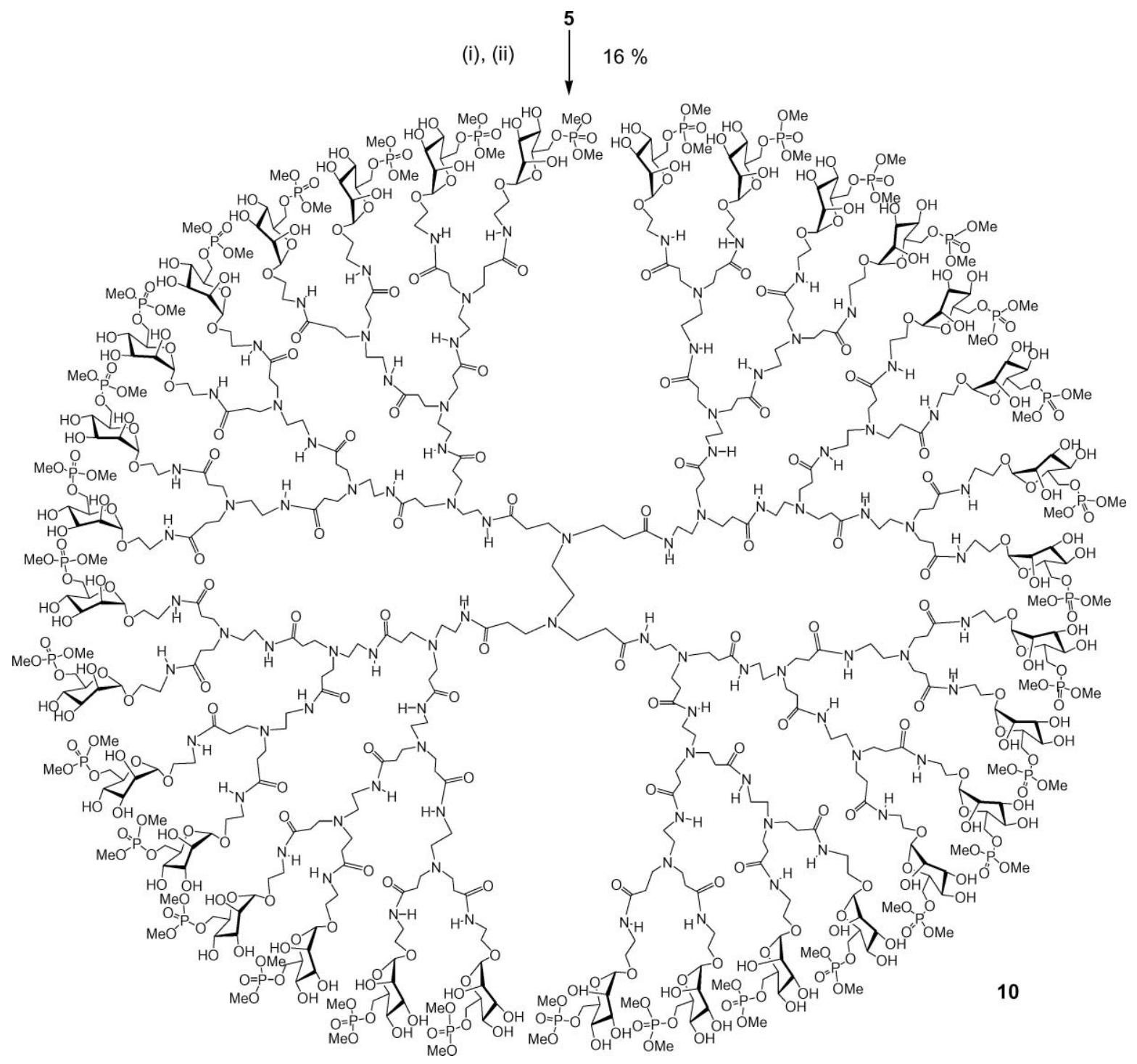

Scheme 4 Reagents and conditions: (i) PAMAM G ${ }_{3.5}-(\mathrm{COOH})_{32}$, EDC/NHS, DMF, rt, 24 h; (ii) $0.5 \mathrm{M} \mathrm{NaOMe} / \mathrm{MeOH}, \mathrm{rt}, 12 \mathrm{~h}$.

goat liver receptor was shown to bind the receptor protein efficiently. The results are shown in the Fig. 1. The figure

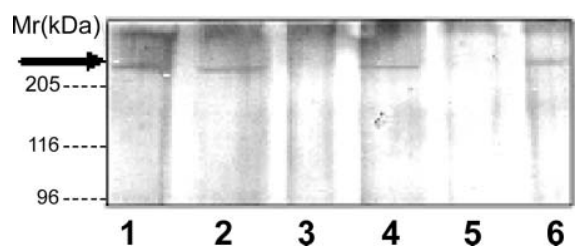

Fig. $17.5 \%$ SDS-PAGE analysis of the purified goat MPR 300 protein (silver staining); $4 \mu \mathrm{g}$ of protein applied on all gels. Lane 1: purified goat liver MPR 300 protein, bound and eluted from phosphomannan gel; lanes 2, 4, and 6 are the receptor protein bound and eluted from the Seralose-M, Seralose-T and Seralose-O gels, respectively (the arrow indicates the position of the receptor protein); lanes $\mathbf{3}$ and $\mathbf{5}$ : no protein applied. shows that the band pattern is similar in intensity for all three compounds subjected in this study, and this pattern suggests that the protein binds to all gels to a similar extent, including the phosphomannan gel which was used as a control. From previous work it is known that the pentamannosyl-phosphate and phosphomannan coupled as functional appendages to Sepharose via divinylsulfone can be used efficiently for the purification of the MPR 300 proteins from goat liver. ${ }^{12}$

\section{Conclusions}

In conclusion, a series of phosphorylated sugar-containing cluster glycosides was prepared. In this instance, Man-6-P sugar units were installed at the peripheries of various PAMAM dendritic scaffolds. The simultaneous multiple functionalizations were efficient, and nearly complete substitutions 
were achieved with the PAMAM dendritic scaffolds of up to four generations. A number of dendritic cluster glycosides incorporated at the peripheries of PAMAM dendrimers were known previously. ${ }^{13}$ Moderate increases in binding potencies of dendritic cluster glycosides with relvant lectins have also been observed often. ${ }^{14}$ While important issues relating to the structural and topological requirements of dendritic clustered sugar ligands for an efficient lectin binding remain at an early stage of generalization, ${ }^{15}$ the incorporation of dendritic design principles itself is established firmly, so as to obtain newer types of cluster glycosides. The phosphorylated sugar-containing dendrimers reported herein should thus add further to the repertoire of dendritic cluster glycosides. Preliminary biological results obtained in this study suggest that the purified goat liver MPR 300 protein can bind on the affinity adsorbents prepared and can be eluted with $7.5 \mathrm{mM}$ mannose 6-phosphate. It would be interesting to see if the matrices prepared can also bind the receptor isolated from other animal species. Further, it remains to be etablished whether the MPR 46 protein can also bind on these matrices. The ready availability of the synthetic compunds should allow further experimentation in the preparation of the affinity gels and analysis of their various functions, such as binding and interaction with the putative mannose 6-phosphate receptor proteins, namely, MPR 300 and 46.

\section{Experimental}

\section{General methods}

All solvents were dried prior to use according to literature methods. ${ }^{16} \mathrm{Et}_{3} \mathrm{~N}$ was dried over $\mathrm{CaH}_{2}$ and distilled freshly prior to use. Analytical TLC was performed on silica gel 60-F254 (Merck) with detection by fluorescence and/or by charring following immersion in $5 \% \mathrm{H}_{2} \mathrm{SO}_{4} / \mathrm{EtOH}$. GPC was performed on a Waters HPLC pump/dual $\lambda$ absorbance detector using a phenogel column $(5 \mu \mathrm{m}, 500 \AA)$ and solvent THF (flow rate: $\left.1 \mathrm{~mL} \mathrm{~min}{ }^{-1}\right)$. Silica gel (100-200 mesh) was used for column chromatography. ${ }^{1} \mathrm{H}$ and ${ }^{13} \mathrm{C}$ NMR spectra were recorded either on a spectrometer operating at 300 and $75 \mathrm{MHz}$, respectively, or a spectrometer operating at 400 and $100 \mathrm{MHz}$, respectively. ${ }^{31} \mathrm{P}$ NMR spectra were recorded using a spectrometer operating at $162 \mathrm{MHz}$. Tetramethylsilane or residual solvent signal formed the internal reference for the NMR spectra. The following abbreviations were used to denote the signal multiplicities: $\mathrm{s}$, singlet; d, doublet; $\mathrm{t}$, triplet; $\mathrm{m}$, multiplet; dd, double doublet; app. s, apparent singlet; app. d, apparent doublet; app. t, apparent triplet; band, several overlapping signals; $A B$ q, $A B$ type quartet; br, broad; br. s, broad singlet.

$\mathrm{N}$-(Benzyloxycarbonylamino) ethyl-2,3,4,-tri- $\mathrm{O}$-benzoyl-6- $\mathrm{O}$ trityl-a-D-mannopyranoside (2). A suspension of $\mathbf{1}^{17}(0.375 \mathrm{~g}$, $0.484 \mathrm{mmol}$ ) in $\mathrm{MeOH}$ was admixed with $\mathrm{NaOMe} / \mathrm{MeOH}$ $(0.5 \mathrm{M}, 0.5 \mathrm{~mL})$ and left stirring for $6 \mathrm{~h}$, neutralized with Amberlite IR-120 resin $\left(\mathrm{H}^{+}\right.$form), filtered and the filtrate concentrated in vacuo. The resulting solid was triturated with $\mathrm{Et}_{2} \mathrm{O}$ and dried thoroughly to afford a white solid. This product was suspended in a mixture of trityl chloride $(0.175 \mathrm{~g}$, $0.63 \mathrm{mmol})$, DMAP $(0.020 \mathrm{~g})$ and $\mathrm{C}_{5} \mathrm{H}_{5} \mathrm{~N}(10 \mathrm{~mL})$ and heated for $3 \mathrm{~h}$. The reaction mixture was then allowed to come to room temperature, cooled to $0{ }^{\circ} \mathrm{C}$ and $\mathrm{BzCl}(1.0 \mathrm{~mL})$ was added before stirring for $12 \mathrm{~h}$. The reaction mixture was diluted with $\mathrm{Et}_{2} \mathrm{O}(20 \mathrm{~mL})$, washed with aqueous $\mathrm{NaHCO}_{3}(10 \%$; $2 \times 15 \mathrm{~mL})$, aqueous $\mathrm{NaHSO}_{3}(5 \% ; 2 \times 15 \mathrm{~mL})$, followed by $\mathrm{H}_{2} \mathrm{O}(2 \times 20 \mathrm{~mL})$. The organic layer was dried $\left(\mathrm{Na}_{2} \mathrm{SO}_{4}\right)$ and concentrated in vacuo to obtain a residue, which was purified (EtOAc-petroleum ether $=3: 7)$ to afford $2(0.304 \mathrm{~g}, 69 \%)$ as a white foamy solid. TLC: $R_{\mathrm{f}} 0.65$ (EtOAc-petroleum ether $=3$ : 7). ${ }^{1} \mathrm{H}$ NMR $\left(300 \mathrm{MHz}, \mathrm{CDCl}_{3}\right): \delta 8.15(2 \mathrm{H}, \mathrm{d}, J=7.2 \mathrm{~Hz})$, $7.83(2 \mathrm{H}, \mathrm{d}, J=7.5 \mathrm{~Hz}), 7.73(2 \mathrm{H}, \mathrm{d}, J=6.9 \mathrm{~Hz}), 7.51-7.07$ $(29 \mathrm{H}$, band $), 6.04(1 \mathrm{H}, \mathrm{t}, J=9.9 \mathrm{~Hz}), 5.76(1 \mathrm{H}, \mathrm{dd}, J=3.3$, $10.5 \mathrm{~Hz}), 5.70$ (1 H, app. s), 5.35 (1 H, app. t), 5.12 (3 H, m), 4.16
(1 H, m), 3.93 (1 H, m), 3.72 (1 H, m), 3.59-3.24 (4 H, band); ${ }^{13} \mathrm{C} \mathrm{NMR}\left(75 \mathrm{MHz}, \mathrm{CDCl}_{3}\right): \delta 165.6,165.0,156.4,143.6,136.4$, 133.5, 133.1, 133.0, 130.1, 129.9-128.1, 127.7, 126.8, 97.9, 86.7, 70.7, 70.6, 70.4, 67.8, 66.8, 66.7, 62.1, 40.9. ESI-MS: calc. for $\mathrm{C}_{56} \mathrm{H}_{49} \mathrm{NO}_{11}: m / z: 934.3203[\mathrm{M}+\mathrm{Na}]^{+}$; found: $934.3182[\mathrm{M}+$ $\mathrm{Na}]^{+}$.

$N$-(Benzyloxycarbonylamino)ethyl-2,3,4-tri- $O$-benzoyl- $\alpha$-Dmannopyranoside (3). A suspension of $2(0.120 \mathrm{~g}, 0.131 \mathrm{mmol})$ in $\mathrm{HCOOH}-\mathrm{THF}-\mathrm{H}_{2} \mathrm{O}(1: 1: 0.1,5 \mathrm{~mL})$ was heated at $50{ }^{\circ} \mathrm{C}$ for $2 \mathrm{~h}$. Solvents were removed in vacuo, the residue co-evaporated with $\mathrm{PhMe}(2 \times 5 \mathrm{~mL})$ and purified (EtOAc-petroleum ether $=$ $3: 2)$ to furnish $3(0.082 \mathrm{~g}, 93 \%)$ as a glassy solid. TLC: $R_{\mathrm{f}} 0.71$ (EtOAc-petroleum ether $=3: 2) .[\alpha]_{\mathrm{D}}^{24}-48.00^{\circ}\left(c 2.0, \mathrm{CHCl}_{3}\right)$. ${ }^{1} \mathrm{H}$ NMR (300 MHz, $\left.\mathrm{CDCl}_{3}\right): \delta 8.09(2 \mathrm{H}, \mathrm{d}, J=7.2 \mathrm{~Hz}), 7.97$ $(2 \mathrm{H}, \mathrm{d}, J=7.2 \mathrm{~Hz}), 7.82(2 \mathrm{H}, \mathrm{d}, J=7.5 \mathrm{~Hz}), 7.62-7.24(14$ $\mathrm{H}$, band), $5.93(1 \mathrm{H}, \mathrm{dd}, J=3.6,10.2 \mathrm{~Hz}), 5.83(1 \mathrm{H}, \mathrm{t}, J=$ $9.9 \mathrm{~Hz}), 5.68(1 \mathrm{H}, \mathrm{m}), 5.29(1 \mathrm{H}, \mathrm{m}), 5.13(3 \mathrm{H}, \mathrm{m}), 4.06-4.02$ (1 H, m), 3.92-3.50 (6 H, band); ${ }^{13} \mathrm{C}$ NMR (75 MHz, $\left.\mathrm{CDCl}_{3}\right)$ : $\delta 166.4,165.5,156.4,136.3,133.7,133.6,133.2,129.9,129.7$, 129.1, 128.9-128.1, 97.9, 71.2, 70.4, 69.5, 67.7, 67.1, 66.9, 61.3, 40.8. ESI-MS: calc. for $\mathrm{C}_{37} \mathrm{H}_{35} \mathrm{NO}_{11}: m / z: 692.2108[\mathrm{M}+\mathrm{Na}]^{+}$; found: $692.2129[\mathrm{M}+\mathrm{Na}]^{+}$.

2-Aminoethyl-6- $O$-dimethylphosphoryl-2,3,4-tri- $O$-benzoyl- $\alpha$ D-mannopyranoside (5). Chlorodimethyl phosphate $(90 \mu \mathrm{L}$, $0.636 \mathrm{mmol}$ ) was added slowly to a stirring solution of 3 $(0.215 \mathrm{~g}, 0.321 \mathrm{mmol})$, in $\mathrm{C}_{5} \mathrm{H}_{5} \mathrm{~N}(2 \mathrm{~mL})$ at $-40{ }^{\circ} \mathrm{C}$. The reaction mixture was allowed to reach room temperature, stirred for $24 \mathrm{~h}$ and the solvents removed, the residue was dissolved in $\mathrm{CH}_{2} \mathrm{Cl}_{2}(15 \mathrm{~mL})$, filtered and the filtrate evaporated in vacuo. The resulting residue was purified (EtOAc-petroleum ether $=4: 1)$ to afford $4(0.236 \mathrm{~g}, 94 \%)$ as a viscous syrup. TLC: $R_{\mathrm{f}} 0.62($ EtOAc-petroleum ether $=4: 1)$. $[\alpha]_{\mathrm{D}}^{24}-25.50^{\circ}$ (c 5.0, $\mathrm{CHCl}_{3}$ ). ${ }^{1} \mathrm{H} \mathrm{NMR}\left(400 \mathrm{MHz}, \mathrm{CDCl}_{3}\right): \delta 8.07(2 \mathrm{H}, \mathrm{dd}$, $J=1.3,8.4 \mathrm{~Hz}), 7.95(2 \mathrm{H}$, app. d), $7.80(2 \mathrm{H}, \mathrm{dd}, J=1.2,8.4$ $\mathrm{Hz}), 7.60-7.22(14 \mathrm{H}$, band), $5.89(1 \mathrm{H}, \mathrm{t}, J=10.1 \mathrm{~Hz}), 5.84$ $(1 \mathrm{H}, \mathrm{dd}, J=3.2,10.1 \mathrm{~Hz}), 5.65(1 \mathrm{H}, \mathrm{m}), 5.39(1 \mathrm{H}$, app. t), $5.11(2 \mathrm{H}, \mathrm{s}), 5.03(1 \mathrm{H}, \mathrm{d}, J=2.0 \mathrm{~Hz}), 4.26-4.23(3 \mathrm{H}, \mathrm{m}), 3.92$ $(1 \mathrm{H}, \mathrm{m}), 3.75-3.65(6 \mathrm{H}, \mathrm{dd}, J=11.4 \mathrm{~Hz}), 3.60-3.48(3 \mathrm{H}$, $\mathrm{m}) ;{ }^{13} \mathrm{C}$ NMR $\left(75 \mathrm{MHz}, \mathrm{CDCl}_{3}\right): \delta 165.4,156.4,136.4,133.6$, 133.5, 133.2, 129.9-128.1, 97.7, 70.3, 69.8, 69.7, 67.9, 66.8, 66.5, 66.0, 65.9, 54.5, 40.8; ${ }^{31} \mathrm{P}$ NMR (162 $\left.\mathrm{MHz}, \mathrm{CDCl}_{3}\right): \delta 1.10$ ESI-MS: calc. for $\mathrm{C}_{39} \mathrm{H}_{40} \mathrm{NO}_{14} \mathrm{P}: m / z: 800.2084[\mathrm{M}+\mathrm{Na}]^{+}$; found: $800.2085[\mathrm{M}+\mathrm{Na}]^{+}$. For 5: a suspension of $4(0.152 \mathrm{~g}$, $0.195 \mathrm{mmol})$ in $\mathrm{MeOH}-$ EtOAc $(4: 1,20 \mathrm{~mL})$ and $\mathrm{Pd}-\mathrm{C}(10 \%$; $0.020 \mathrm{~g}$ ) was subjected to hydrogenolysis using $\mathrm{H}_{2}$ gas for $12 \mathrm{~h}$. After filtration over Celite, the solvents were removed in vacuo to yield $5(0.115 \mathrm{~g}, 92 \%)$ as a white foamy solid. TLC: $R_{\mathrm{f}} 0.11$ (EtOAc).

$\mathrm{N}$-(Benzyloxycarbonylamino)ethyl-6- $\mathrm{O}$-dimethylphosphoryl$\boldsymbol{\alpha}$-D-mannopyranoside (6). A suspension of $\mathbf{4}(0.052 \mathrm{~g}$, $0.066 \mathrm{mmol})$ in $\mathrm{MeOH}(5 \mathrm{~mL})$ was admixed with $\mathrm{NaOMe}-$ $\mathrm{MeOH}(0.5 \mathrm{M}, 0.2 \mathrm{~mL})$ and left stirring for $12 \mathrm{~h}$, neutralized with Amberlite IR-120 resin $\left(\mathrm{H}^{+}\right.$form), filtered and the filtrate concentrated in vacuo. The residue was dissolved in $\mathrm{H}_{2} \mathrm{O}(1 \mathrm{~mL})$ and washed with EtOAc $(2 \times 1 \mathrm{~mL})$, evaporated in vacuo to obtain $6(0.030 \mathrm{~g}, 97 \%)$ as a colourless glassy solid. $[a]_{\mathrm{D}}^{24}-7.25^{\circ}$ (c $\left.1.2, \mathrm{H}_{2} \mathrm{O}\right) .{ }^{1} \mathrm{H}$ NMR $\left(400 \mathrm{MHz}, \mathrm{D}_{2} \mathrm{O}\right): \delta 7.29(5 \mathrm{H}, \mathrm{m})$, 4.98 (3 H, m), 4.11-3.21 (16 H, band); ${ }^{13} \mathrm{C}$ NMR (100 MHz, $\left.\mathrm{D}_{2} \mathrm{O}\right): \delta 158.4,136.5,128.8,128.7,128.6,127.7,99.8,72.7,71.2$, $70.4,69.8,67.0,66.5,55.1,40.5 ;{ }^{31} \mathrm{P}$ NMR $\left(162 \mathrm{MHz}, \mathrm{D}_{2} \mathrm{O}\right): \delta$ 1.83. ESI-MS: calc. for $\mathrm{C}_{18} \mathrm{H}_{28} \mathrm{NO}_{11} \mathrm{P}: m / z: 504.1037[\mathrm{M}+\mathrm{K}]^{+}$; found: $504.1004[\mathrm{M}+\mathrm{K}]^{+}$.

4-mer (7). To a mixture of PAMAM G $\mathrm{G}_{0.5}-(\mathrm{COOH})_{4}(0.014 \mathrm{~g}$, $0.040 \mathrm{mmol}), 5(0.138 \mathrm{~g}, 0.214 \mathrm{mmol})$, and HOBt $(0.029 \mathrm{~g}$, $0.199 \mathrm{mmol})$ in DMF $(5 \mathrm{~mL})$ was added DIC $(30 \mu \mathrm{L}, 0.20$ mmol) and stirred at room temperature. After $24 \mathrm{~h}$, solvents were removed in vacuo, the resulting residue was purified via column chromatography $\left(\mathrm{SiO}_{2}, \mathrm{EtOAc}-\mathrm{MeOH}=9: 1\right)$ to afford 
the $O$-benzoyl-protected Man-6-P dendrimer $7(37 \mathrm{mg})$ as a gummy solid. A suspension of the residue in $\mathrm{MeOH}(10 \mathrm{~mL})$ was admixed with $\mathrm{NaOMe} / \mathrm{MeOH}(0.5 \mathrm{M}, 0.2 \mathrm{~mL})$ and left stirring for $3 \mathrm{~h}$, neutralized with Amberlite IR-120 resin $\left(\mathrm{H}^{+}\right.$ form), filtered and the filtrate concentrated in vacuo. The residue was dissolved in $\mathrm{H}_{2} \mathrm{O}(1 \mathrm{~mL})$, washed with EtOAc $(5 \times 1 \mathrm{~mL})$, and evaporated in vacuo to obtain $7(0.021 \mathrm{~g}, 33 \%)$ as a colourless glassy solid. $[\alpha]_{\mathrm{D}}^{24} 27.3^{\circ}\left(c 0.88, \mathrm{H}_{2} \mathrm{O}\right) .{ }^{1} \mathrm{H}$ NMR $\left(400 \mathrm{MHz}, \mathrm{D}_{2} \mathrm{O}\right)$ : $\delta 4.71(4 \mathrm{H}$, app. s, obscured by HOD), $4.15-3.20(76 \mathrm{H}$, band), $2.85\left(8 \mathrm{H}\right.$, br s); ${ }^{13} \mathrm{C}$ NMR $\left(100 \mathrm{MHz}, \mathrm{D}_{2} \mathrm{O}\right): \delta$ 173.9, 99.6, $71.7,70.2,69.9,66.2,65.9,64.8,53.2,50.3,38.9,28.2 ;{ }^{31} \mathrm{P}$ NMR (162 MHz, $\left.\mathrm{D}_{2} \mathrm{O}\right): \delta 1.840$. ESI-MS: $m / z: 420[\mathrm{M} / 4+\mathrm{Na}]^{+}$.

8-mer (8). To a stirring solution of PAMAM G ${ }_{15}-(\mathrm{COOH})_{8}$ $(0.028 \mathrm{~g}, 0.025 \mathrm{mmol})$ and $\mathbf{5}(0.20 \mathrm{~g}, 0.31 \mathrm{mmol})$ in DMF $(3 \mathrm{~mL})$, were added EDC $(0.059 \mathrm{~g}, 0.31 \mathrm{mmol})$ and NHS $(0.036 \mathrm{~g}$, $0.31 \mathrm{mmol}$ ) under an $\mathrm{N}_{2}$ blanket and stirred for $24 \mathrm{~h}$. Solvents were removed, the residue co-evaporated with $\mathrm{PhMe}(2 \times 2 \mathrm{~mL})$, then dissolved in THF $(1 \mathrm{~mL})$ and filtered through a $0.25 \mu \mathrm{m}$ filter. The solution was purified by GPC, and the fraction corresponding to the retention time between 7.40 and $7.48 \mathrm{~min}$ was collected and the solvents removed in vacuo. A suspension of the residue $(32 \mathrm{mg})$ in $\mathrm{MeOH}(15 \mathrm{~mL})$ was admixed with $\mathrm{NaOMe} / \mathrm{MeOH}(0.5 \mathrm{M}, 0.5 \mathrm{~mL})$ and left stirring for $12 \mathrm{~h}$, neutralized with Amberlite IR-120 resin ( $\mathrm{H}^{+}$form), filtered and the filtrate concentrated in vacuo. The residue was dissolved in $\mathrm{H}_{2} \mathrm{O}(1 \mathrm{~mL})$, washed with EtOAc $(5 \times 1 \mathrm{~mL})$, and evaporated in vacuo to obtain $8(0.028 \mathrm{mg}, 31 \%)$ as a white waxy solid. $[\alpha]_{\mathrm{D}}^{24}$ $28.6^{\circ}$ (c $\left.0.60, \mathrm{H}_{2} \mathrm{O}\right) .{ }^{1} \mathrm{H}$ NMR $\left(400 \mathrm{MHz}, \mathrm{D}_{2} \mathrm{O}\right): \delta 4.70(8 \mathrm{H}$, br s), 3.95-3.39 (172 H, band), 3.18-3.07 (24 H, br); ${ }^{13} \mathrm{C}$ NMR $\left(100 \mathrm{MHz}, \mathrm{D}_{2} \mathrm{O}\right): \delta 179.3,176.5,99.6,74.1,73.2,72.7,70.4,69.9$, $69.1,66.2,60.8,58.6,54.9,52.9,48.8,38.9,35.6,33.9 ;{ }^{31} \mathrm{P}$ NMR $\left(162 \mathrm{MHz}, \mathrm{D}_{2} \mathrm{O}\right): \delta 1.80$.

16-mer (9). To a solution of PAMAM $\mathrm{G}_{2.5}-(\mathrm{COOH})_{16}$ $(0.05 \mathrm{~g}, 19.2 \mu \mathrm{mol})$ in DMF $(5 \mathrm{~mL}), 5(0.24 \mathrm{~g}, 0.372 \mathrm{mmol})$, EDC (0.072 g, $0.372 \mathrm{mmol})$ and NHS (0.042 g, $0.372 \mathrm{mmol})$ were added and stirred for $24 \mathrm{~h}$ under an $\mathrm{N}_{2}$ blanket. Solvents were removed, the residue co-evaporated with $\mathrm{PhMe}(2 \times$ $2 \mathrm{~mL})$, dissolved in THF $(1 \mathrm{~mL})$ and filtered through a $0.25 \mu \mathrm{m}$ filter. The solution was purified by GPC and fractions corresponding to the retention time between 7.13 and $7.17 \mathrm{~min}$ were collected and the solvents removed in vacuo. A suspension of the resulting residue $(0.064 \mathrm{~g})$ in $\mathrm{MeOH}(15 \mathrm{~mL})$ was admixed with $\mathrm{NaOMe} / \mathrm{MeOH}(0.5 \mathrm{M}, 0.5 \mathrm{~mL})$ and left stirring for $12 \mathrm{~h}$, neutralized with Amberlite IR-120 resin ( $\mathrm{H}^{+}$form), filtered and the filtrate concentrated. The residue was dissolved in $\mathrm{H}_{2} \mathrm{O}$ $(1 \mathrm{~mL})$, washed with EtOAc $(5 \times 1 \mathrm{~mL})$, and evaporated in vacuo to obtain $9(0.032 \mathrm{~g}, 22 \%)$ as a white waxy solid. The resorcinol assay showed that the product contained 15 16 sugar residues, instead of complete substitution with 16sugar units. Accordingly, the characterization given here refers to the product containing a varying number of sugar units. $[\alpha]_{\mathrm{D}}^{24}$ $27.0^{\circ}\left(c 0.60, \mathrm{H}_{2} \mathrm{O}\right) .{ }^{1} \mathrm{H}$ NMR $\left(400 \mathrm{MHz}, \mathrm{D}_{2} \mathrm{O}\right): \delta 5.17(16 \mathrm{H}$, br s), 3.85-3.41 (256 H, band), 3.43-3.39 (108 H, br), 2.87-2.69 (56 H, br); ${ }^{13} \mathrm{C}$ NMR (100 MHz, $\left.\mathrm{D}_{2} \mathrm{O}\right): \delta 177.4,173.7,172.7$, 99.6, 72.9, 72.7, 70.5, 70.0, 69.9, 66.6, 66.2, 60.8, 59.8, 57.4, 53.0, 52.8, 52.0, 50.6, 44.2, 40.0, 34.5, 30.0; ${ }^{31} \mathrm{P} \mathrm{NMR}\left(162 \mathrm{MHz}, \mathrm{D}_{2} \mathrm{O}\right)$ : $\delta 0.88$.

32-mer (10). To a solution of PAMAM $\mathrm{G}_{3.5}-(\mathrm{COOH})_{32}$ $(0.054 \mathrm{~g}, 9.6 \mu \mathrm{mol})$ in DMF $(5 \mathrm{~mL})$, amine $5(0.240 \mathrm{~g}, 0.36 \mathrm{mmol})$, EDC $(0.072 \mathrm{~g}, 0.36 \mathrm{mmol})$ and NHS $(0.021 \mathrm{~g}, 0.37 \mathrm{mmol})$ were added and stirred for $24 \mathrm{~h}$ under an $\mathrm{N}_{2}$ blanket. Solvents were removed, the residue co-evaporated with $\mathrm{PhMe}(2 \times 2 \mathrm{~mL})$, dissolved in THF $(1 \mathrm{~mL})$ and filtered through a $0.25 \mu \mathrm{m}$ filter. The solution was purified by GPC and the fraction corresponding to the retention time between 6.90 and $7.08 \mathrm{~min}$ was collected and the solvents removed. A suspension of the resulting residue $(0.078 \mathrm{~g})$ in $\mathrm{MeOH}(15 \mathrm{~mL})$ was admixed with $\mathrm{NaOMe} / \mathrm{MeOH}(0.5 \mathrm{M}, 1 \mathrm{~mL})$ and left stirring for $12 \mathrm{~h}$, neutralized with Amberlite IR-120 resin ( $\mathrm{H}^{+}$form), filtered and the filtrate concentrated in vacuo. The residue was dissolved in $\mathrm{H}_{2} \mathrm{O}(1 \mathrm{~mL})$, washed with EtOAc $(5 \times 1 \mathrm{~mL})$, and evaporated in vacuo to obtain $10(0.024 \mathrm{~g}, 16 \%)$ as a white waxy solid. The resorcinol assay showed that the product contained 28-29 sugar residues on average, instead of complete substitution with 32sugar units. Accordingly, the characterization given here refers to the product containing a varying number of sugar units. $[a]_{D}^{24}$ $29.3^{\circ}\left(c 0.58, \mathrm{H}_{2} \mathrm{O}\right) .{ }^{1} \mathrm{H}$ NMR $\left(400 \mathrm{MHz}, \mathrm{D}_{2} \mathrm{O}\right): \delta 4.89(27-30 \mathrm{H}$, br s), 4.13-3.20 (695-746 H, band), 3.11-2.55 (120 H, br); ${ }^{13} \mathrm{C}$ NMR (100 MHz, $\left.\mathrm{D}_{2} \mathrm{O}\right): \delta 174.5,172.9,165.7,99.8,71.9,71.7$, 70.4, 69.9, 66.7, 66.4, 65.3, 64.6, 63.6, 62.5, 60.8, 58.6, 57.4, 52.9, 49.8, 39.1, 37.6, 33.7; ${ }^{31} \mathrm{P}$ NMR (162 MHz, $\left.\mathrm{D}_{2} \mathrm{O}\right): \delta 1.49$.

\section{Resorcinol assay}

To each U-shaped well of a 96-well microtiter plate were added $20 \mu \mathrm{L}$ of the derivatives $\mathbf{7 - 1 0}$ plus $20 \mu \mathrm{L}$ of a $6 \mathrm{mg} \mathrm{mL}^{-1}$ solution of resorcinol plus $100 \mu \mathrm{L}$ of $75 \% \mathrm{H}_{2} \mathrm{SO}_{4}$ plus $50 \mu \mathrm{L}$ pristane. The solutions were homogenized by shaking the plate with a vortex apparatus. The plates were heated at $90{ }^{\circ} \mathrm{C}$ in an oven for $30 \mathrm{~min}$ and subsequently kept at room temperature for $30 \mathrm{~min}$, in the dark. The optical density of each well was recorded automatically by using a microtiter plate reader Wallac Victor 1420 multilabel counter equipped with an interference filter at $430 \mathrm{~nm}$. The concentration of sugar present in the aliquots of glycodendrimer solutions was determined from the plot of absorbance $v s$. concentration of $\alpha$-D-mannose $\left(\mu \mathrm{g} \mu \mathrm{L}^{-1}\right)$, as determined from a solution of $\alpha$-D-mannose taken as the standard.

\section{Preparation of affinity gels and testing their ability to bind purified goat liver mannose 6-phosphate receptor (MPR 300) protein}

Goat liver MPR 300 protein was purified on prepared Sepharose-divinyl sulfone-phosphomannan gel. ${ }^{12}$ The monomeric $(\mathrm{M})$, tetrametric $(\mathrm{T})$ and the octameric $(\mathrm{O})$ compounds were separately coupled to $500 \mu \mathrm{L}$ of Seralose $4 \mathrm{~B}$ gel (SRL Chemicals) that had been activated with divinyl sulfone as described, except that in place of Sepharose gel, Seralose gel was used and in place of pentamannosylphosphate, the synthetic compounds prepared were used. ${ }^{18}$ Purified goat liver MPR 300 protein was applied separately to $250 \mu \mathrm{L}$ portions of these gels equilibrated with column buffer $(50 \mathrm{mM}$ imidazole- $\mathrm{HCl}$ buffer $\mathrm{pH} 7.0,0.15 \mathrm{M} \mathrm{NaCl}, 5 \mathrm{mM}$ sodium $\beta$-glycerophosphate, $2 \mathrm{mM}$ EDTA, $0.05 \%$ Triton X-100) in an Eppendorf tube overnight at $4{ }^{\circ} \mathrm{C}$. The gel was packed into a column, washed with $1.0 \mathrm{~mL}$ of column buffer, followed by $1.0 \mathrm{~mL}$ of $7.5 \mathrm{mM}$ mannose 6-phosphate in column buffer. Eluted samples were TCA precipitated and analyzed on $7.5 \%$ SDS-PAGE under reducing conditions as described, ${ }^{19}$ and the protein bands detected by silver staining. ${ }^{20}$

\section{Acknowledgements}

We thank the Department of Science and Technology, New Delhi, India and Third World Academy Sciences, Trieste, Italy, for financial support of this work. S. K. N. thanks the Department of Science and Technology, New Delhi, India for a research support on the mannose 6-phosphate receptor proteins (SR/SO/BB-60/2003).

\section{References}

1 B. J. Mengeling and S. J. Turco, Curr. Opin. Struct. Biol., 1998, 8, 572; D. O. Willenberg, C. R. Parish, W. B. Cowden and J. Curtin, FASEB J., 1989, 3, 1968; S. Kornfeld, Annu. Rev. Biochem., 1992, 61, 46; E. Barreto-Bergter and P. A. J. Gorin, Adv. Carbohydr. Chem. Biochem., 1983, 41, 67.

2 M. J. McConville and M. A. J. Ferguson, Biochem. J., 1993, 294, 305. 
3 S. Kornfeld, Annu. Rev. Biochem., 1992, 61,307; K. von Figura and A. Hasilik, Аnпи. Rev. Biochem., 1986, 55, 167; A. Varki and S. Kornfeld, J. Biol. Chem., 1980, 255, 10847; A. Varki and S. Kornfeld, J. Biol. Chem., 1983, 258, 2808; P. Ghosh, N. M. Dahms and S. Kornfeld, Nature Rev.: Mol. Cell Biol., 2003, 4, 202.

4 H. Tomada, Y. Ohsumi, Y. Ichikawa, O. P. Srivastava, Y. Kishimoto and Y. C. Lee, Carbohydr. Res., 1991, 213, 37.

5 Y. C. Lee and R. T. Lee, Neoglycoconjugates: Preparation and Applications, ed. Y. C. Lee, Academic Press, San Diego, 1994, p. 23.

6 R. Roy, Curr. Opin. Struct. Biol., 1996, 6, 692; N. Jayaraman, S. A. Nepogodiev and J. F. Stoddart, Chem.-Eur. J., 1997, 3, 1193; T. K. Dam and C. F. Brewer, Chem. Rev., 2002, 102, 387; J. J. Lundquist and E. J. Toone, Chem. Rev., 2002, 102, 555; M. J. Cloninger, Curr. Opin. Chem. Biol., 2002, 6, 742; T. K. Lindhorst, Top. Curr. Chem., 2002, 218, 217.

7 For a few recent reports, see: J. J. Garcia-Lopez, F. HernandezMatero, J. Isac-Garcia, J. M. Kim, R. Roy, F. Santoyo-Gonzalez and A. Vargas-Berenguel, J. Org. Chem., 1999, 64, 522; M. Takahashi, Y. Hara, K. Aoshima, H. Kurihara, T. Oshikawa and M. Yamashita, Tetrahedron Lett., 2000, 41, 8485; R. Roy and J. M. Kim, Tetrahedron, 2003, 59, 3881; D. Arosio, I. Vrasidas, P. Valentini, R. M. J. Liskamp, R. J. Pieters and A. Bernardi, Org. Biomol. Chem., 2004, 2, 2113; E. K. Woller and M. J. Cloninger, Biomacromolecules, 2001, 2, 1052; E. K. Woller and M. J. Cloninger, Org. Lett., 2002, 4, 7.

8 D. A. Tomalia, H. Baker, J. Dewald, M. Hall, C. Kallos, S. Martin, J. Roeck, J. Ryder and P. Smith, Polym. J. (Tokyo), 1985, 17, 117.

9 M. Monsigny, C. Petit and A.-C. Roche, Anal. Biochem., 1988, 175, 525.

10 E. Duverger, C. Pellerin-Mendes, R. Mayer, A.-C. Roche and M. Monsigny, J. Cell Sci., 1995, 108, 1325; E. Duverger, A. Coppin, G. Strecker and M. Monsigny, Glycoconjugate J., 1999, 16, 793; T.
Bettinger, J.-S. Remy and P. Erbacher, Bioconjugate Chem., 1999, 10, $558 ;$ K. Kunath, A. von Harpe, D. Fischer and T. Kissel, J. Controlled Release, 2003, 88, 159.

11 K. Suresh, V. S. N. Raju and N. S. Kumar, Glycoconjugate J., 2004 20, 257.

12 K. Suresh, M. Ramanadham and N. S. Kumar, J. Biochem. Biophys. Methods, 2002, 52, 111.

13 K. Aoi, K. Itoh and M. Okada, Macromolecules, 1995, 28, 5391; D. Zanini and R. Roy, J. Org. Chem., 1998, 63, 3486; T. Toyokuni and A. K. Singhal, Chem. Soc. Rev., 1995, 231; T. K. Lindhorst and C. Kieburg, Angew. Chem., Int. Ed. Engl., 1996, 35, 1953.

14 For example, see: D. Zanini and R. Roy, J. Am. Chem. Soc., 1997, 119, 2088; J. P. Thompson and C.-L. Schengrund, Glycoconjugate J., 1997, 14, 837; S. M. Dimick, S. C. Powell, S. A. McMahon, D. N. Moothoo, J. H. Naismith and E. J. Toone, J. Am. Chem. Soc., 1999 , 121, 10286 ; S. André, P. J. C. Ortega, M. A. Perez, R. Roy and H. J. Gabius, Glycobiology, 1999, 9, 1253; T. K. Dam, R. Roy, S. K. Das, S. Oscarson and C. F. Brewer, J. Biol. Chem., 2000, 275, 14223 ; A. Nelson, J. M. Belitsky, S. Vidal, C. S. Joiner, L. G. Baum and J. F. Stoddart, J. Am. Chem. Soc., 2004, 126, 11914.

15 E. Fan, Z. Zhang, W. E. Minke, Z. Hou, C. L. M. J. Verlinde and W. G. J. Hol, J. Am. Chem. Soc, 2000, 122, 2663; P. I. Kitov, J. M. Sadowska, G. Mulvey, G. D. Armstrong, H. Ling, N. S. Pannu, R. J. Read and D. R. Bundle, Nature, 2000, 403, 669.

16 D. D. Perrin and W. L. F. Armarego, Purification of Laboratory Chemicals, Pergamon Press, Oxford, 3rd edn., 1988.

17 O. Srinivas, B. Muktha, S. Radhika, T. N. Guru Row and N. Jayaraman, Carbohydr. Res., 2004, 339, 1087.

18 N. S. Kumar, J. Biochem. Biophy. Methods, 1996, 31, 181.

19 U. K. Laemmli, Nature, 1970, 227, 6800

20 W. Ansorge, J. Biochem. Biophys. Methods, 1985, 11, 13. 